\title{
Molecular detection of Anaplasma species in dogs in Colombia
}

\author{
Detecçáo molecular de espécies de Anaplasma em cães na Colômbia \\ Giovanni Vargas-Hernandez ${ }^{1,2}$; Marcos Rogério André2 ; Diana Maria Cendales ${ }^{1}$; Keyla Carstens Marques de Sousa ${ }^{2}$; \\ Luiz Ricardo Gonçalves²; Mariana Cristina Hoeppner Rondelli³; Rosangela Zacarias Machado²; Mirela Tinucci-Costa ${ }^{2 *}$ \\ ${ }^{1}$ Departamento de Salud Animal, Facultad de Medicina Veterinaria y de Zootecnia, Universidad Nacional de Colombia, Bogotá, \\ Colombia \\ ${ }^{2}$ Faculdade de Ciências Agrárias e Veterinárias - FCAV, Universidade Estadual Paulista - UNESP, Jaboticabal, SP, Brasil \\ ${ }^{3}$ Instituto Federal de Educação, Ciência e Tecnologia do Sul de Minas Gerais - IFSULDEMINAS, Muzambinho, MG, Brasil
}

Received August 15, 2016

Accepted September 26, 2016

\begin{abstract}
Anaplasma platys and A. phagocytophilum are tick-borne pathogens that parasitize platelets and neutrophils, respectively, of humans and animals. The former is the etiological agent of canine cyclic thrombocytopenia, while the latter is that of canine granulocytic anaplasmosis. This work involved the detection and identification of Anaplasma species in blood samples from dogs in Colombia, using molecular techniques. Between December 2008 and April 2009, blood samples were drawn from the cephalic vein of 91 dogs in the central-western region of Colombia (cities of Bogota, Villavicencio and Bucaramanga) and stored in tubes containing EDTA. These samples were used in 16S rRNA-Anaplasma spp. nPCR and the preparation of blood smears. One (1.1\%) of the 91 sampled dogs showed inclusions suggestive of Anaplasmataceae agents in the cytoplasm of platelets. Based on PCR followed by sequencing and phylogenetic analysis, $A$. platys and Anaplasma sp. closed related to $A$. phagocytophilum were detected in two and one dog, respectively. Interestingly, all the samples were negative for specific msp-2-A. phagocytophilum real-time qPCR, suggesting the circulation of an Anaplasma species phylogenetically related to A. phagocytophilum in dogs in the aforementioned region. Hence, Anaplasma spp. circulates among dogs in Colombia, albeit with low frequency. To the best of authors' knowledge, this is the first molecular detection of Anaplasma spp. in dogs in Colombia.
\end{abstract}

Keywords: Dogs, Anaplasma spp., Anaplasma platys, Colombia.

\section{Resumo}

Anaplasma platys e $A$. phagocytophilum são patógenos transmitidos por carrapatos que parasitam plaquetas e neutrófilos, respectivamente, de humanos e animais. Enquanto o primeiro é agente etiológico da trombocitopenia cíclica canina, o último é o agente responsável pela anaplasmose granulocítica canina. O presente trabalho objetivou detectar e caracterizar, utiizando técnicas moleculares, a presença de espécies de Anaplasma em amostras de sague de cáes na Colômbia. Entre Dezembro de 2008 e Abril de 2009, amostras de sangue colhidas em tubos contendo EDTA da veia cefálica de 91 cães da região centro-oeste da Colômbia (cidades de Bogotá, Villavicencio e Bucaramanga). As amostras de sangue foram utilizadas em reaçóes de nPCR para 16S rRNA-Anaplasma spp. e confecção de esfregaços sanguíneos. Um (1,1\%) dos 91 cães amostrados mostraram inclusôes sugestivas de agentes Anaplasmataceae no citoplasma de plaquetas. Baseada na PCR seguida de sequenciamento e análise filogenética, A. platys and Anaplasma sp. relacionado a A. phagocytophilum foram detectados em dois e um cão, respectivamente. Interessantemente, todas as amostras mostraram-se negativas na PCR em tempo real quantitativa específica para msp-2-A. phagocytophilum, sugerindo a circulaçáo de uma espécie de Anaplasma sp. filogeneticamente relacionado ao $A$. phagocytophilum em cães na regiáo estudada. Embora em uma baixa freqüência, Anaplasma spp. circula entre cães na Colômbia. O presente trabalho representa a primeira detecção de Anaplasma spp. em cães na Colômbia.

Palavras-chave: Cães, Anaplasma spp., Anaplasma platys, Colômbia.

\footnotetext{
*Corresponding author: Mirela Tiniccu-Costa. Departamento de Clínica e

Cirurgia Veterinária, Faculdade de Ciências Agrárias e Veterinárias - FCAV,

Universidade Estadual Paulista - UNESP, Campus de Jaboticabal, Via de Acesso

Prof. Paulo Donato Castellane, s/n, Zona Rural, CEP 14884-900, Jaboticabal,

SP, Brasil.e-mail: mirelatc@fcav.unesp.br
} 


\section{Introduction}

Anaplasma species (Rickettsiales: Anaplasmataceae) are gram-negative obligate intracellular bacteria that can parasitize domestic and wild animals as well as humans (DUMLER et al., 2001; ISMAIL et al., 2010).

Anaplasma phagocytophilum, the etiological agent of human granulocytic anaplasmosis (HGA), equine granulocytic anaplasmosis (EGA), and tick-borne fever in ruminants, parasitizes neutrophils and eosinophils, whose biological cycle is preserved in the environment by ticks of the Ixodes persulcatus species complex and vertebrate reservoirs (DUMLER et al., 2001). In the USA, the Ixodes scapularis tick is responsible for the transmission of $A$. phagocytophilum in the northeast and mid-west, while the I. pacificus tick species is involved in the transmission of the agent on the country's Pacific coast (BARLOUGH et al., 1997; LEVIN \& FISH, 2001). In humans, HGA is characterized by fever, headache, myalgia, chills, and malaise (WOLDEHIWET, 2010). Dogs may play a role as reservoirs for $A$. phagocytophilum (OTEO \& BROUQUI, 2005). The clinical signs found in $A$. phagocytophilum-infected dogs vary from a subclinical infection to an acute febrile condition accompanied by anorexia and lethargy. Central nervous system dysfunction and lameness have also been recorded in canine anaplasmosis by $A$. phagocytophilum (LESTER et al., 2005).

Anaplasma platys is a bacterial species that infects predominantly canine blood platelets, causing canine cyclic thrombocytopenia, which is characterized by depression, fever, hemorrhage, and thrombocytopenia. The vector suspected of transmitting the pathogen is the brown dog tick, Rhipicephalus sanguineus (BEAUFILS et al., 2002).

Several reports have been published about the occurrence of these agents in South America (DAGNONE et al., 2009; MACHADO et al., 2012; SACCHI et al., 2012; SALVAGNI et al., 2010; SANTOS et al., 2009, 2011, 2013; SILVEIRA et al., 2014; ANDRÉ et al., 2012, 2014). In Colombia, although a 20\% seroprevalence to $A$. phagocytophilum has been found among rural workers in the country's northern region, the agent has not yet been characterized molecularly in mammals (MÁTTAR \& PARRA, 2006). This study involved the detection and identification of Anaplasma species in blood samples from dogs in Colombia, using molecular techniques.

\section{Material and Methods}

Between December 2008 and April 2009, blood samples were drawn from the cephalic vein of 91 dogs in the central-western region of Colombia and stored in tubes containing EDTA. The dogs were distributed as follows: 21 dogs from the city of Bogotá (used for the detection of explosives in several regions of the country), 31 dogs from the city of Villavicencio (21 from an animal shelter and 10 from the local Zoonosis Control Center), and 39 dogs from the city of Bucaramanga (19 dogs from a local veterinary clinic and 20 from animal shelters). The selection criteria was based on a history of tick infestation. Blood smears were fixed with methanol and stained with Giemsa (Giemsa stain, modified, Sigma-Aldrich, St. Louis, MO, USA).
DNA was extracted from aliquots of $200 \mu \mathrm{L}$ of whole blood, using a commercial kit (QIAamp DNA Blood Mini kit, QIAGEN, Valencia, CA, USA) according to the manufacturer's instructions. Each sample of extracted DNA $(5 \mu \mathrm{L})$ was used as a template in a $25 \mu \mathrm{L}$ nested PCR reaction based on the sequence of the $16 \mathrm{~S}$ rRNA (MASSUNG et al., 1998) and groESL genes (NICHOLSON et al., 1999). The mixture contained 10X PCR buffer (Life Technologies, Carlsbad, CA, USA), $1.0 \mathrm{mM} \mathrm{MgCl}_{2}$ (Life Technologies, Carlsbad, CA, USA), $0.2 \mathrm{mM}$ deoxynucleotide triphosphate (dNTPs) mixture (Life Technologies, Carlsbad, CA, USA), 1.5 U Taq DNA Polymerase (Life Technologies, Carlsbad, CA, USA), and $0.5 \mu \mathrm{M}$ of each primer (Integrated DNA Technologies, Coralville, IA, USA). The sequence of primers based on 16 rRNA and groESL gene was respectively, gE3a (5'-CACATGCAAGTCGAACGGATTATTC-3'), gE10R (5'- TTCCGTTAAGAAGGATCTAATCTCC-3') and HS1a (5'-AITGGGCTGGTAITGAAAT-3'), EHR-CS778R (5'- CCICCIGGIACIAIACCTTC-3') in the first reaction, and gE2 (5'- GGCAGTATTAAAAGCAGCTCCAGG-3'), gE9f (5'-AACGGATTATTCTTTATAGCTTGCT-3') and HS43 (5'-AT(A/T)GC(A/T)AA(G/A)GAAGCATAGTC-3'), HSVR (5'-CTCAACAGCAGCTCTAGTAGC-3') in the second reaction. One micro liter of DNA amplified in the first reaction was used as DNA template in the second reaction. Anaplasma platys DNA positive control was obtained from a naturally infected dog in Brazil (DAGNONE et al., 2009). Anaplasma phagocytophilum DNA positive control was kindly supplied by Dr. John Stephen Dumler (University of Maryland, Baltimore, MD, USA). Ultra-pure sterile water (Promega, Wis., USA) was used as negative control. PCR amplifications in the first and second reactions based on 16SrRNA were performed at $94{ }^{\circ} \mathrm{C}$ for $5 \mathrm{~min}$, followed by 40 repetitive cycles of $94^{\circ} \mathrm{C}$ for $30 \mathrm{sec}, 55^{\circ} \mathrm{C}$ for $30 \mathrm{sec}$, and $72^{\circ} \mathrm{C}$ for $1 \mathrm{~min}$, and ending with a final extension at $72^{\circ} \mathrm{C}$ for $5 \mathrm{~min}$ in a thermal cycler (T100 Thermal Cycler, Bio-Rad, Hercules, CA, USA). For the PCR amplifications based on groESL gene three primary cycles at $94^{\circ} \mathrm{C}$ for $1 \mathrm{~min}, 48^{\circ} \mathrm{C}$ for $2 \mathrm{~min}$ and $72{ }^{\circ} \mathrm{C}$ for $90 \mathrm{sec}$ were followed by 37 repetitive cycles of $94^{\circ} \mathrm{C}$ for $1 \mathrm{~min}$, $48{ }^{\circ} \mathrm{C}$ for $1 \mathrm{~min}$ and $72{ }^{\circ} \mathrm{C}$ for $90 \mathrm{sec}$ and ending with a final extension at $72{ }^{\circ} \mathrm{C}$ for $5 \mathrm{~min}$ in a thermal cycler (T100 Thermal Cycler, Bio-Rad, Hercules, CA, USA). In the second reaction the temperature of annealing was increased to $55^{\circ} \mathrm{C}$.

To avoid PCR contamination, the DNA extraction, reaction setup, PCR amplification and electrophoresis were performed in separate rooms. The reaction products were purified using a commercial kit (Silica Bead DNA Gel Extraction Kit, Thermo Scientific, Waltham, Mass., USA).

Purified amplified DNA fragments were subjected in-house to sequence confirmation in an automatic sequencer (ABI Prism 310 Genetic Analyzer - Applied Biosystems by Life Technologies, Carlsbad, CA, USA) and were used for subsequent phylogenetic analysis. Phylogenetic reconstructions were based on DNA sequence alignment of positive samples. Consensus sequences were obtained through the analysis of the sense and antisense sequences, using the CAP3 program (http://mobyle.pasteur.fr/ cgi-bin/MobylePortal/portal.py). Comparisons were made with sequences deposited in GenBank, using the basic local alignment search tool (BLAST) (ALTSCHUL et al., 1990). The sequences were aligned with sequences published in GenBank using 
Clustal/W (THOMPSON et al., 1994) in Bioedit v. 7.0.5.3 (HALL, 1999). Phylogenetic inference was based on maximum likelihood (ML) inference. The ML phylogenies were inferred with RAxMLHPC BlackBox 7.6.3 software (STAMATAKIS et al., 2008) (which includes an estimation of bootstrap node support) through the CIPRES Science Gateway, using a GTR + GAMMA model of evolution and 1000 bootstrapping replicates. The best model of evolution was selected by the program jModelTest 2 on XSEDE (DARRIBA et al., 2012) under the Akaike Information Criterion (AIC) (POSADA \& BUCKLEY, 2004), through the CIPRES Science Gateway. The trees were visualized in Treegraph 2.0.56-381 beta (STOVER \& MULLER, 2010).

Each sample of extracted DNA was also used as a template in $10 \mu \mathrm{L}$ real-time qPCR assay, according to Drazenovich et al. (2006). The mixtures contained $5 \mu \mathrm{L}$ of buffer (GoTaq qPCR Master Mix, Promega, Wis., USA,) a final concentration of $1 \mu \mathrm{M}$ of each primer ([903f: 5' AGTTTGACTGGAACACACCTGATC-3'] and [1024r: 5' CTCGTAACCAATCTCAAGCTCAAC-3']) and TaqMan-probe

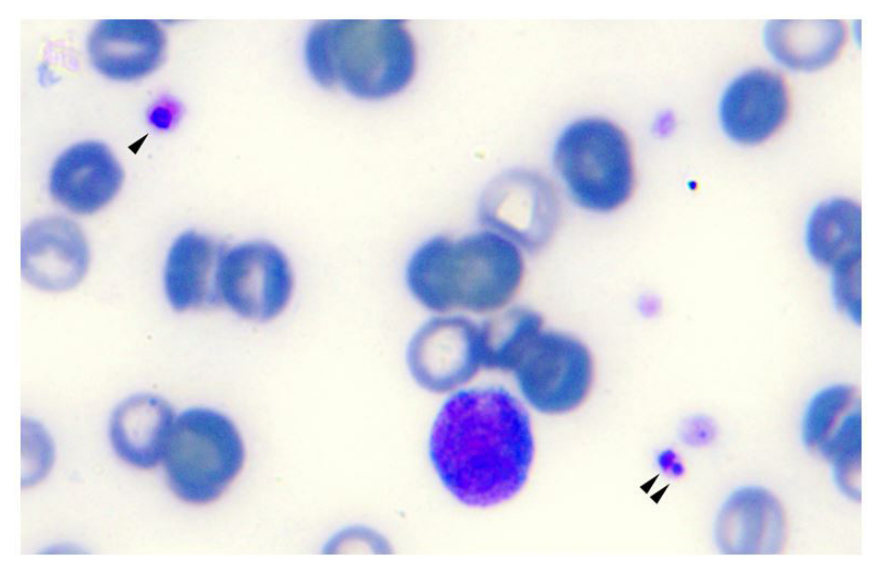

Figure 1. Giemsa-stained blood smear from an Anaplasma platysPCR positive dog, showing inclusions in platelets (arrows). Light microscopy under $1000 \mathrm{X}$ magnification. (939p FAM -TTAAGGACAACATGCTTGTAGCTATGGAAGGCATAMRA) Integrated DNA Technologies, Coralville, IA, USA) and $1 \mu \mathrm{L}$ of DNA sample. qPCR amplifications were performed in a thermal cycler (CFX96 Thermal Cycler, Bio-Rad, Hercules, CA, USA). The amplification conditions were $50^{\circ} \mathrm{C}$ for $2 \mathrm{~min}, 95^{\circ} \mathrm{C}$ for $10 \mathrm{~min}$ followed by 45 cycles of $95^{\circ} \mathrm{C}$ for $15 \mathrm{~s}$ and $60{ }^{\circ} \mathrm{C}$ for $1 \mathrm{~min}$. Standard curves were constructed using 10 -fold serial dilutions of gBlock gene fragments (Integrated DNA Technologies, Coralville, IA, USA) encoding $m s p 2-A$. phagocytophilum fragment. The number of copies was determined according to the formula $\left(\mathrm{X} \mathrm{g} / \mu \mathrm{L}\right.$ DNA/ [fragment length in bp x 660] $\times 6.022 \times 10^{23}$ $\times$ copies $/ \mu \mathrm{L}$.

\section{Results}

One (1.1\%) of the 91 sampled dogs showed inclusions suggestive of Anaplasmataceae agents in the cytoplasm of platelets (Figure 1). This animal came from an animal shelter in the city of Bucaramanga. Among the 91 dogs, three (3.3\%) sampled in Bucaramanga city were positive for Anaplasma spp. in the PCR assay based on $16 \mathrm{~S}$ rRNA gene; two of them showed clinical signs suggestive of hemoparasitosis. All the samples tested were negative at groESL nPCR. The BLAST analysis, A. platys ( $99 \%$ of identity with $A$. platys detected in dogs in Thailand [EF139459]) and Anaplasma sp. (99\% of identity with A. phagocytophilum isolated in the USA [CP006616]) were identified as the species found in two dogs (one of them showing inclusions in platelets as well as clinical signs [Figure 1]) and one sampled dog (also showing clinical signs), respectively (Figure 2). The phylogenetic tree based on 16S rRNA gene showed that one sequence was located in the same clade than an $A$. platys sequence detected in a domestic cat from Brazil (KC989957) with bootstrap valuie of 83 (Figure 2); the other sequence obtained was positioned in the same clade than an $A$. platys sequence detected in a dog in Rio de Janeiro, Brazil (FJ755157) and A. platys strain Gigio

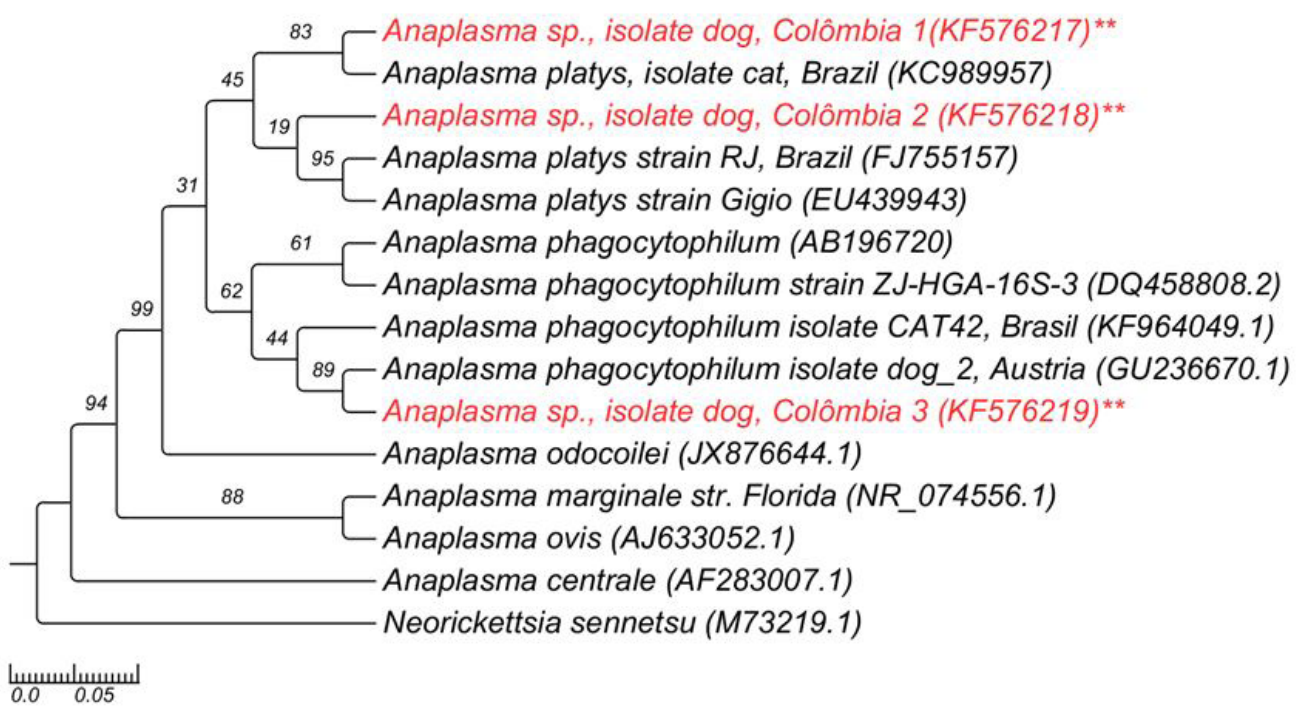

Figure 2. Phylogenetic tree of Anaplasma spp. (16SrRNA) based on maximum likelihood, using GTR+G+I as model of evolution. Numbers correspond to bootstrap values over $50{ }^{* *}$ Sequences from the present study. 
(EU439943), Italy, but without significant clade support $(\geq 50)$ (Figure 2). The other sequence obtained was grouped with a A. phagocytophilum sequence detected in a dog from Austria, with bootstrap value of 89 (Figure 2). The size of the alignment used to perform the phylogenetic analysis was approximately 600pb. Anaplasma platys and Anaplasma sp. closed related to A. phagocytophilum $16 \mathrm{~S}$ rRNA sequences found in dogs from Colombia were deposited in GenBank under accession numbers KF576217, KF576218, and KF576219, respectively. All the samples tested were negative by the specific msp-2-A. phagocytophilum qPCR. The efficiency of qPCR assay was $\mathrm{E}=90.0 \%$ (slope $=-3.588$; $\mathrm{r} 2=0.995)$. The $\mathrm{qPCR}$ assay followed the Minimum Information for publication of Quantitative real-time PCR Experiments (BUSTIN et al., 2009).

\section{Discussion}

This work reports on the first molecular evidence of infection by Anaplasma spp. in dogs from Colombia. Anaplasma platys was molecularly detected in two (2.2\%) out of 91 sampled dogs. One of these dogs (Dog\#56) showed clinical symptoms and hematological abnormalities suggestive of tick-borne disease (depression, dehydration, anorexia, pale mucous membranes, vomiting, leucopenia $\left[6500 \times 10^{3} / \mu \mathrm{L}-\operatorname{ref} 6700-17000\right]$ and severe thrombocytopenia $\left[52000 \times 10^{3} / \mu \mathrm{L}\right.$ - ref. $\left.150.000-500.000\right]$ (data not shown), and had been previously diagnosed with $E$. canis by molecular techniques VARGAS-HERNANDEZ et al., 2012a). The other $\operatorname{dog}$ positive for A. platys (Dog\#72), showing inclusions in platelets was co-infected with E. canis and Hepatozoon canis, based on previous studies (VARGAS-HERNANDEZ et al., 2012a, b), but showed no clinical symptoms compatible with hemoparasitosis (data not shown). It is worth to mention that, among the dogs with clinical symptoms of anaplasmosis, one of the samples was found to be closely related to $A$. phagocytophilum, based on the phylogenetic analysis. Such dog exhibited hematological findings suggestive of canine anaplasmosis (dehydration, fever, anorexia, hemoconcentration [63\%] thrombocytopenia $\left[57000 \times 10^{3} / \mu \mathrm{L}\right.$ - ref. 150.000-500.000]).

Diagnostics based solely on the presence of inclusions in platelets by blood smear exams shows poor sensitivity because of the low and transient bacteremia presented by this agent (BEAUFILS et al., 2002). The presence of positive PCR and blood smear results associated with clinical symptoms suggests the occurrence of the acute phase of the disease at the time of blood sampling. This underscores the importance of molecular techniques in the differential diagnosis of tick-borne diseases. The presence of positive PCR and blood smear results associated with clinical symptoms suggests the occurrence of the acute phase of the disease at the time of blood sampling.

The molecular prevalence (3.3\%) of Anaplasma spp. among the dogs sampled in this study was lower than that found for E. canis $(40.6 \%)$ and Babesia vogeli $(5.5 \%)$ in our previous study (VARGAS-HERNÁNDEZ et al., 2012a). The criteria for selection of dogs can influence the low detection of the agent, dogs with clinical signs should be more likely to present positive results in Anaplasma nPCRs (DAGNONE et al., 2009). Similar results have been found among dogs without clinical signs from central-western Brazil (SOUSA et al., 2013).

In South America, $A$. platys and has been molecular detected in dogs in Brazil (DAGNONE et al., 2009; SANTOS et al., 2009; SOUSA et al., 2013), Argentina (EIRAS et al., 2013; OSCHEROV et al., 2011), Chile (ABARCA et al., 2007), and Venezuela (HUANG et al., 2005). Anaplasma spp. phylogenetically similar to $A$. platys has been detected in marsh deer in Brazil (SACCHI et al., 2012).

One of detected sequences was found to be closely related to A. phagocytophilum, based on 16S rRNA phylogenetic analysis. Miranda \& Mattar (2015), using a nested PCR and phylogenetic approach based on 16SrRNA gene, also found similar results when analyzed sequences obtained from Dermacentor nitens collected from horses in Colombia. However, all the samples from the present study showed negative results at $A$. phagocytophilum msp-2 $\mathrm{qPCR}$, which is proven to be a more sensitive and specific protocol for $A$. phagocytophilum detection than nPCR based on 16SrRNA (DRAZENOVICH et al., 2006). These results suggest that there may be possibly a closely related species but not the same as A. phagocytophilum-like agent circulating in Colombia. Although A. phagocytophilum has already been detected in dogs (SANTOS et al. 2011, 2013) and brown brocket deer (SILVEIRA et al., 2014) in Brazil, previous reports also have found new genotypes of Anaplasma spp. phylogenetically similar to A. phagocytophilum in wild carnivores kept in captivity in zoos (ANDRÉ et al., 2012), wild birds (MACHADO et al., 2012) and in cats (ANDRÉ et al., 2014) in Brazil, corroborating with the findings of the present study. Besides that, $A$. phagocytophilum antibodies have been found among rural workers in the northern region of the Colombia and among horses in Brazil (SALVAGNI et al., 2010), however, the agent has not yet been molecularly characterized (MÁTTAR \& PARRA, 2006).

Although, the tick species implicated in transmission routes of Anaplasma spp. in dogs from south America remain unknown, the presence of co-infection with E. canis, H. canis and Anaplasma spp., found in our previous studies (VARGAS-HERNANDEZ et al., 2012a, b) using the same sampled dogs, reinforce the hypothesis that these pathogens could share the same vector. Rhipicephalus sanguineus, Rhipicephalus (Boophilus) microplus, Amblyomma maculatum, and Ornithodoros (Alectorobius) puertoricensis have been found parasitizing dogs in Colombia (ACERO et al., 2011; MIRANDA \& MATTAR, 2015; PATERNINA et al., 2009). In Brazil it has been molecularly detected A. phagocytophilum in A. cajennense and $R$. sanguineus ticks (SANTOS et al., 2013) and Argentina (OSCHEROV et al., 2011).

The real impact of multiple pathogens on the pathogenesis of these infections and the host's response to them remains unknown; hence, studies focusing on this issue are sorely needed. Albeit with low prevalence, Anaplasma spp. circulates among dogs in Colombia. Investigations into the zoonotic potential of the Anaplasma spp. closely related $A$. phagocytophilum agent detected in this study and the real role of dogs in the epidemiology of human granulocytic anaplasmosis in Colombia are much needed. 


\section{Acknowledgements}

The authors gratefully acknowledge the Brazilian research funding agency FAPESP (São Paulo Research Foundation) for its financial support of this work, and CNPq (National Council for Scientific and Technological Development) for granting a scholarship to the first author, G. Vargas-Hernandez.

\section{References}

Acero EJ, Calixto OJ, Prieto AC. Garrapatas (Acari: Ixodidae) prevalentes en caninos no migrantes del noroccidente de Bogotá, Colombia. NOVA 2011; 9(15): 113-214.

Abarca K, López J, Perret C, Guerrero J, Godoy P, Veloz A, et al. Anaplasma platys in dogs, Chile. Emerg Infect Dis 2007; 13(9): 13921395. PMid:18252119. http://dx.doi.org/10.3201/eid1309.070021.

Altschul SF, Gish W, Miller W, Myers EW, Lipman DJ. Basic local alignment search tool. J Mol Biol 1990; 215(3): 403-410. PMid:2231712. http://dx.doi.org/10.1016/S0022-2836(05)80360-2.

André MR, Denardi NCB, Sousa KCM, Gonçalves LR, Henrique PC, Ontivero CRGR, et al. Arthropod-borne pathogens circulating in freeroaming domestic cats in a zoo environment in Brazil. Ticks Tick Borne Dis 2014; 5(5): 545-551. PMid:24889035. http://dx.doi.org/10.1016/j. ttbdis.2014.03.011.

André MR, Dumler JS, Scorpio DG, Teixeira RH, Allegretti SM, Machado RZ. Molecular detection of tick-borne bacterial agents in Brazilian and exotic captive carnivores. Ticks Tick Borne Dis 2012; 3(4): 247-253. PMid:22749737. http://dx.doi.org/10.1016/j.ttbdis.2012.04.002.

Barlough JE, Madigan JE, Kramer VL, Clover JR, Hui LT, Webb JP, et al. Ehrlichia phagocytophila Genogroup Rickettsiae in ixodid ticks from California collected in 1995 and 1996. J Clin Microbiol 1997; 35(8): 2018-2021. PMid:9230373.

Beaufils JP, Inokuma H, Martin-Granel J, Jumelle P, Barbault-Jumelle M, Brouqui P. Anaplasma platys (Ehrlichia platys) infection in a dog in France: description of the case, and characterization of the agent. Revue Méd Vét 2002; 153(2): 85-90.

Bustin SA, Benes V, Garson JA, Hellemans J, Huggett J, Kubista $\mathrm{M}$, et al. The MIQE guidelines: minimum information for publication of quantitative real-time PCR experiments. Clin Chem 2009; 55(4): 611622. PMid:19246619. http://dx.doi.org/10.1373/clinchem.2008.112797.

Dagnone AS, Souza AI, André MR, Machado RZ. Molecular diagnosis of Anaplasmataceae organisms in dogs with clinical and microscopical signs of ehrlichiosis. Rev Bras Parasitol Vet 2009; 18(4): 20-25. PMid:20040204. http://dx.doi.org/10.4322/rbpv.01804004.

Darriba D, Taboada GL, Doallo R, Posada D. jModelTest 2: more models, new heuristics and parallel computing. Nat Methods 2012; 9(8): 772. PMid:22847109. http://dx.doi.org/10.1038/nmeth.2109.

Drazenovich N, Foley J, Brown RN. Use of Real-Time Quantitative PCR Targeting the $m s p 2$ protein gene to identify cryptic Anaplasma phagocytophilum infections in wildlife and domestic animals. Vector Borne Zoonotic Dis 2006; 6(1): 83-90. PMid:16584330. http://dx.doi. org/10.1089/vbz.2006.6.83.

Dumler JS, Barbet AF, Bekker CP, Dasch GA, Palmer GH, Ray SC, et al. Reorganization of genera in the families Rickettsiaceae and Anaplasmataceae in the order Rickettsiales: unification of some species of Ehrlichia with
Anaplasma, Cowdria with Ehrlichia and Ehrlichia with Neorickettsia, descriptions of six new species combinations and designation of Ehrlichia equi and 'HGE agent' as subjective synonyms of Ehrlichia phagocytophila. Int J Syst Evol Microbiol 2001; 51(6): 2145-2165. PMid:11760958. http://dx.doi.org/10.1099/00207713-51-6-2145.

Eiras DF, Craviotto MB, Vezzani D, Eyal O, Baneth G. First description of natural Ehrlichia canis and Anaplasma platys infections in dogs from Argentina. Comp Immunol Microbiol Infect Dis 2013; 36(2): 169-173. PMid:23273677. http://dx.doi.org/10.1016/j.cimid.2012.11.008.

Hall TA. BioEdit: a user-friendly biological sequence alignment editor and analysis program for Windows 95/98/NT. Nucleic Acids Symp Ser 1999; 41: 95-98.

Huang H, Unver A, Perez M, Orellana NG, Rikihisa Y. Prevalence and molecular analysis of Anaplasma platys in dogs in Lara, Venezuela. Braz J Microbiol 2005; 36(3): 211-216. http://dx.doi.org/10.1590/S151783822005000300002

Ismail N, Bloch KC, McBride JW. Human Ehrlichiosis and Anaplasmosis. Clin Lab Med 2010; 30(1): 261-292. PMid:20513551. http://dx.doi. org/10.1016/j.cll.2009.10.004.

Lester SL, Breitschwerdt EB, Collis CD, Hegarty BC. Anaplasma phagocytophilum infection (granulocytic anaplasmosis) in a dog from Vancouver Island. Can Vet J 2005; 46(9): 825-827. PMid:16231653.

Levin ML, Fish D. Interference between the agents of Lyme disease and human granulocytic ehrlichiosis in a natural reservoir host. Vector Borne Zoonotic Dis 2001; 1(2): 139-148. PMid:12653144. http://dx.doi.org/ $10.1089 / 153036601316977741$.

Machado RZ, André MR, Werther K, Sousa E, Gavioli FA, Alves JR Jr. Migratory and carnivorous birds in Brazil: reservoirs for Anaplasma and Ehrlichia species? Vector Borne Zoonotic Dis 2012; 12(8): 705-708. PMid:22607070. http://dx.doi.org/10.1089/vbz.2011.0803.

Massung RF, Slater K, Owens JH, Nicholson WL, Mather TN, Solberg VB, et al. Nested PCR assay for detection of Granulocytic Ehrlichiae. J Clin Microbiol 1998; 36(4): 1090-1095. PMid:9542943.

Máttar S, Parra M. Detection of antibodies to Anaplasma, Bartonella and Coxiella in rural inhabitants of the Caribbean area of Colombia. Revista MVZ Córdoba 2006; 11(2): 781-789.

Miranda J, Mattar S. Molecular detection of Anaplasma sp. and Ehrlichia sp. in ticks collected in domestical animals, Colombia. Trop Biomed 2015; 32(4): 726-735.

Nicholson WL, Castro MB, Kramer VL, Sumner JW, Childs JE. Duskyfooted wood rats (Neotoma fuscipes) as reservoirs of granulocytic Ehrlichiae (Rickettsiales: Ehrlichieae) in northern California. J Clin Microbiol 1999; 37(10): 3323-3327. PMid:10488199.

Oscherov EB, Milano AMF, Lobo B, Anda P, Escudero R. Detection of Anaplasma platys and other pathogens in ectoparasites from urban hosts in Northeast Argentine. Rev Ibero-Latinoam Parasitol 201 1; 70(1): 42-48.

Oteo JA, Brouqui P. Ehrlichiosis y anaplasmosis humana. Enferm Infecc Microbiol Clin 2005; 23(6): 375-380. PMid:15970171. http://dx.doi. org/10.1157/13076178

Paternina LE, Díaz-Olmos Y, Paternina-Gómez M, Bejarano EE. Canis familiaris, un nuevo hospedero de Ornithodoros (A.) puertoricensis Fox, 1947 (Acari: Ixodida) en Colombia. Acta Biol Colombiana 2009; 14(1): 153-160.

Posada D, Buckley TR. Model selection and model averaging in phylogenetics: advantages of akaike information criterion and bayesian approaches over likelihood ratio tests. Syst Biol 2004; 53(5): 793-808. PMid:15545256. http://dx.doi.org/10.1080/10635150490522304. 
Sacchi ABV, Duarte JMB, André MR, Machado RZ. Prevalence and molecular characterization of Anaplasmataceae agents in free-ranging Brazilian marsh deer (Blastocerus dichotomus). Comp Immunol Microbiol Infect Dis 2012; 35(4): 325-334. PMid:22381686. http://dx.doi. org/10.1016/j.cimid.2012.02.001.

Salvagni CA, Dagnone AS, Gomes TS, Mota JS, Andrade GM, Baldani $\mathrm{CD}$, et al. Serologic evidence of equine granulocytic anaplasmosis in horses from central West Brazil. Rev Bras Parasitol Vet 2010; 19(3): 135-140. PMid:20943015. http://dx.doi.org/10.1590/S1984-29612010000300002.

Santos F, Coppede JS, Pereira AL, Oliveira LP, Roberto PG, Benedetti $\mathrm{RB}$, et al. Molecular evaluation of the incidence of Ehrlichia canis, Anaplasma platys and Babesia spp. in dogs from Ribeirão Preto, Brazil. Vet J2009; 179(1): 145-148. PMid:17920967. http://dx.doi.org/10.1016/j. tvjl.2007.08.017.

Santos HA, Pires MS, Vilela JAR, Santos TM, Faccini JL, Baldani $\mathrm{CD}$, et al. Detection of Anaplasma phagocytophilum in Brazilian dogs by real-time polymerase chain reaction. J Vet Diagn Invest 2011; 23(4): 770774. PMid:21908321. http://dx.doi.org/10.1177/1040638711406974.

Santos HA, Thomé SM, Baldani CD, Silva CB, Peixoto MP, Pires MS, et al. Molecular epidemiology of the emerging zoonosis agent Anaplasma phagocytophilum (Foggie, 1949) in dogs and ixodid ticks in Brazil. Parasit Vectors 2013; 6(1): 348. PMid:24330631. http://dx.doi. org/10.1186/1756-3305-6-348.

Silveira JAG, Rabelo EML, Lima PCS, Chaves BN, Ribeiro MFB. Postmortem hemoparasite detection in free-living Brazilian brown brocket deer (Mazama gouazoubira, Fischer, 1814). Rev Bras Parasitol Vet 2014; 23(2): 206-215. PMid:25054500. http://dx.doi.org/10.1590/S198429612014035.
Sousa KC, André MR, Herrera HM, Andrade GB, Jusi MM, Santos LL, et al. Molecular and serological detection of tick-borne pathogens in dogs from an area endemic for Leishmania infantum in Mato Grosso do Sul, Brazil. Rev Bras Parasitol Vet 2013; 22(4): 525-531. PMid:24473877. http://dx.doi.org/10.1590/S1984-29612013000400012.

Stamatakis A, Hoover P, Rougemont J. A rapid bootstrap algorithm for the RAxML Web servers. Syst Biol 2008; 57(5): 758-771. PMid: 18853362. http://dx.doi.org/10.1080/10635150802429642.

Stover BC, Muller KF. TreeGraph 2: Combining and visualizing evidence from different phylogenetic analyses. BMC Bioinformatics 2010; 11(1): 7. PMid:20051126. http://dx.doi.org/10.1186/1471-2105-11-7.

Thompson JD, Higgins DG, Gibson TJ. CLUSTAL W: improving the sensitivity of progressive multiple sequence alignment through sequence weighting, position specific gap penalties and weight matrix choice. Nucleic Acids Res 1994; 22(22): 4673-4680. PMid:7984417. http:// dx.doi.org/10.1093/nar/22.22.4673.

Vargas-Hernández G, André MR, Faria JL, Munhoz TD, HernandezRodriguez M, Machado RZ, et al. Molecular and serological detection of Ehrlichia canis and Babesia vogeli in dogs in Colombia. Vet Parasitol 2012a; 186(3-4): 254-260. PMid:22130333. http://dx.doi.org/10.1016/j. vetpar.2011.11.011.

Vargas-Hernández G, André MR, Munhoz TD, Faria JL, Machado RZ, Tinucci-Costa M. Molecular characterization of Hepatozoon canis in dogs from Colombia. Parasitol Res 2012b; 110(1): 489-492. PMid:22068216. http://dx.doi.org/10.1007/s00436-011-2634-7.

Woldehiwet Z. The natural history of Anaplasma phagocytophilum. Vet Parasitol 2010; 167(2-4): 108-122. PMid:19811878. http://dx.doi. org/10.1016/j.vetpar.2009.09.013. 